\title{
Life Cycle Assessment as Entrepreneurial Tool for Business Management and Green Innovations
}

\author{
Cassiano Moro Piekarski', Leila Mendes da Luz², Lidiana Zocche ${ }^{3}$,Antonio Carlos de Francisco ${ }^{4}$
}

\begin{abstract}
A transition for a green economy has encouraged companies to use new tools which promote internal corporate entrepreneurship, increase the competitiveness and achieve sustainable results. This article presented a theoretical discussion of how the Life Cycle Assessment (LCA) can presents as an entrepreneurial tool for modern business management and green innovation. Studies of LCA were analyzed showing benefits and applications in the areas of strategic planning, production, process of development of products, search and development, social and environmental responsibility, and marketing. As for green innovations, there were analyzed studies of innovations in products, processes and services. The tool assists in making sustainable decisions, fortifies the management of the business processes, the management of operations and the promotion of greener innovations.
\end{abstract}

Keywords: business management; corporate entrepreneurship; green innovation; internal entrepreneurship; life cycle assessment (LCA); sustainability.

Department of Production Engineering, Federal University of Technology - Paraná (UTFPR),Av. Monteiro Lobato, Km 04, s/n - Ponta Grossa, Brazil. 84016-210. Phone: +554232204876.

email: 'cassianopiekarski@gmail.com, ${ }^{2}$ leila.mendesdaluz@gmail.com, ${ }^{3}$ lidianazocche@gmail.com, ${ }^{4}$ acfrancisco@utfpr.edu.br.

ISSN: 07 I8-2724. (http://www.jotmi.org)

Journal of Technology Management \& Innovation (C) Universidad Alberto Hurtado, Facultad de Economía y Negocios. 


\section{Introduction}

Practices that are consolidated in business environments are those that meet the needs and demands of their times. Recent studies view entrepreneurship as the engine of sustainable development, expecting that the innovation of entrepreneurship will bring about the next industrial revolution and a more sustainable future (Pacheco, Dean and, Payne, 2010).

Entrepreneurship and sustainability in corporate posture is necessary for firms to reach greater competitiveness. As example, investments in innovation committed to sustainable actions is a concrete way to add value to Brazilian products and to overcome the barriers to and conditioners of international operations and competitiveness (Gomes, Kruglianskas and, Scherer, 20II). Additionally, also evidence that the best performing companies have an innovative behavior (Sánches, et al. 20II). In this perspective, to move towards a sustainable value creation, companies must be more entrepreneurial, taking into account the adoption of tools to incorporate sustainable aspects in their results and associating it throughout the products, processes and services life cycle. The Life Cycle Assessment (LCA) is a methodological tool that evaluates the impact and environmental aspects of a product, process or service throughout its complete or partial life cycle. All the relations of the chain are analyzed (materials, supply chain, distribution, use and final destination).
LCA is used as a tool for evaluating the environmental performance of products, processes and services to form a practice for sustainable business management. Studies show that LCA can collaborate to entrepreneurship in various areas of business (Varžinskas, Staniškis and Knašyte, 20I2; De Benedetto and Klemeš, 2009; Koffler, Schebek and Krinke, 2008; Gaudreault, Samson and Stuart, 2010), as well as in the spreading of green innovations (Manda, Blok and Patel, 20I2; Abdallah et al., 2012). Actions of entrepreneurship, including new tools, are vital for social and economic development, especially in Latin America (Bas, Amoros and Kunc, 2008).

In this context, this article aims to discuss theoretically LCA as an entrepreneurial tool for firms achieve sustainable results through of renewed vision about business management and green innovations. Were analyzed results of LCA studies that showed benefits and applications in different areas of business management that had promoted green innovations in products, processes and services.

\section{Life cycle assessment}

LCA has developed rapidly over the past three decades (Guinée et al., 20II).The development of the methodology started from a mere analysis of energy and environmental burdens of products, during the 1970's, and currently is widely being used by researchers, organizations and indus-

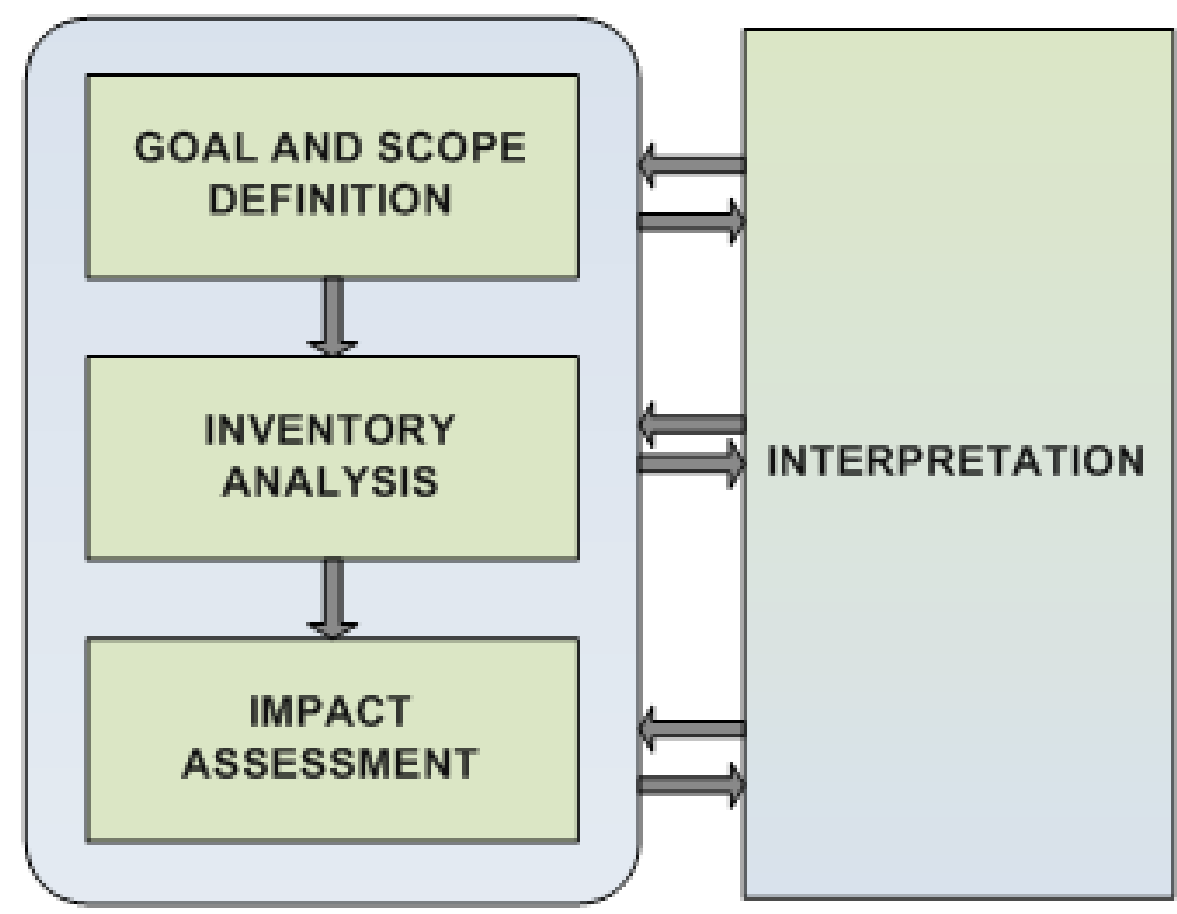

Figure I. Stages of an LCA. Data from ISO, 2006

ISSN: 07 I8-2724. (http://www.jotmi.org)

Journal of Technology Management \& Innovation (c) Universidad Alberto Hurtado, Facultad de Economía y Negocios. 
tries (Garrigues et al., 20I2). LCA seeks to quantify the use of natural resources, emissions, environmental impacts and health impacts associated with the products, processes and services (Welz, Hischer and Hilty, 20I I).

LCA methodology is structured and internationally standardized by the ISO I4040 series (ISO, 2006a; ISO, 2006b). They are considered the main and most important standards for environmental assessment based on product life cycle and serve as a basis for other more specific standards such as ISO 14025 (Environmental Product Declaration), ISO 14067 (carbon footprint), ISO 14045 (eco-efficiency), among others (Klöpffer, 20I2).

The method is rapidly developing into an important tool for authorities, companies and individuals in environmental and sustainable science (Roy et al., 2009). Figure I shows the stages of LCA methodology (ISO, 2006a).

The first stage "Goal and Scope Definition" is perhaps the most important component of an LCA because the study is carried out according to the statements made in this phase (Roy et al., 2009).At this stage it is necessary to identify the purpose of the analysis, the system boundaries, the functional unit (FU) and assumptions. Given the subjective characteristics of this activity, it is necessary to be transparent with regards to all decisions and assumptions for this phase of the analysis. The goals and scope can be adjusted during the iterative process of the LCA (Benedetto and Klemes, 2009). The Inventory Analysis stage involves the Life Cycle Inventory $(\mathrm{LCl})$ of the LCA methodology. It is essentially the collection of the data (Shafie et al., 20I2). The objective is to perform mass and energy balances to quantify all the materials and energy inputs, as well as wastes and emissions from the system that cause the environmental burdens (Benedetto and Klemes, 2009). Inputs are raw materials, energies, water, etc. Outputs are the products and co-products, emission to air, water and soil, and wastes (Roy et al., 2009).

The impact assessment in LCA consists of the following elements: classification, characterization, normalization and valuation (Roy et al., 2009). The phase is based on the aggregation of the environmental impacts quantified in the inventory analysis into a limited set of recognizable impact categories (e.g. climate change, global warming, ozone depletion, acidification, eutrophication) (Benedetto and Klemes, 2009). The last stage purpose of an LCA is to draw conclusions that can support a decision or can provide a readily understandable result of an LCA (Roy et al., 2009). Interpretation is a procedure to evaluate the information from the inventory analysis and impact assessment of the system and to propose conclusions from all of the previous results of the study (Benedetto and Klemes, 2009).
Life Cycle Assessment (LCA) is the most quantitative (and complex) tool which may assist in: identifying opportunities to improve the environmental performance of products, process and services, supporting decision makers, selecting environmental indicators of environmental performance, and others (Bocken et al., 20I2). The unique characteristic of LCA in focusing its application from the perspective of the product life cycle (Finnveden et al., 2009) providing a large part of environmental information necessary to interpret, anticipate and undertake sustainable solutions.

\section{LCA as an entrepreneurial tool in business}

With growing recognition that businesses need to more directly support, researchers have begun to explore how entrepreneurship can usefully contribute to the goal of sustainable development (Parrish, 2010). Sustainability-driven entrepreneurs' primary motivation is to contribute to sustainability, whereas a viable, profitable enterprise is a means to that end (Hall, Daneke and, Lenox, 20I0). Sustainable entrepreneurship is thus clearly associated with the promise of more traditional concepts of entrepreneurship, but also brings additional potential both for society and the environment (Kuckertz and Wagner, 20I0). In this perspective, the use of sustainable tools in business can be characterizes as an entrepreneurial approach to competitive advantage.

The use of LCA as an aid to decision making related to sustainable management has become more apparent in the early 1990's (Pieragostini, Mussati and Aguirre, 2012). According to Löfgren, Tillman and Rinde (20II) the modern industrial environment encompasses the life cycle thinking. This implies to consider not only the emissions and use of resources of the company's production process, but also the environmental consequences of all processes related to the product life cycle.

LCA can be applied for numerous reasons. It serves as a source of information that can give support to the management process within organizations. LCA can be widely used as a decision making tool (Liamsanguan and Gheewala, 2008; Borghi et al., 2007). In this perspective, LCA assists managers to find different strategies for an integrated and sustainable management system. It is widely used as a decision-making tool in process selection, design, and optimization in order to identify clean technologies (Borghi et al., 2007).

The use of LCA assists in an internal corporate entrepreneurship. Corporate entrepreneurship improves competitive position and transforms corporations, their markets and industries as opportunities for value creating (Özdemirci, 20I I). Generally speaking, according to Guinée et al. (200I) the LCA can be applied toward objectives for decision-making and value create in different situations: 
- Innovation: LCA is used to assess the environmental impact of product improvements, product development or technical innovations. As pointed out in studies made by Peregrina (2006) and Manda (2012).

- $\quad$ Strategic Planning: An LCA study is conducted to assess the environmental impact of strategic scenarios (Rebitzer and Buxmann, 2005; Poeschl,Ward and Owende, 20I2). - Comparison:An LCA study is conducted to assess whether a product or system meets certain environmental standards, or whether it is more environmentally correct than another product or system (Wang, Templer and Murphy, 2012; Madival et al., 2009).

- $\quad$ Comparative claims disclosed to the public:An LCA study aims to provide an environmental statement about the superiority or equivalence of a product versus a competing product that performs the same function (Menezes, 20I2).

- $\quad$ Promote the development of new products (Madival et al., 2009).

- $\quad$ Analyze the origins of the problems related to particular product and propose improvements (Meneses, 2012; Pasqualino, Meneses and Castells, 20I I; Rebitzer and Buxmann, 2005).
All these factors qualify LCA as the most important methodology in modern industrial environmental management (Löfgren, Tillman and Rinde, 20I I).

The entrepreneurship is increasingly being recognized as a significant conduit for bringing about a transformation to sustainable products and processes (Hall, Daneke and, Lenox, 2010). The entrepreneurship enable firms to become more aggressive, faster, and better at generating novel products, services, and process improvements (Morris et al., Vuuren, Cornwall, Scheepers, 2009). In this sense, LCA is being recognized as an internal entrepreneurial tool to assist different areas of business management and to facilitate the creation of green innovations in firms (Figure 2).

LCA assists various areas of business management, in particular in the areas of business processes and operations. When LCA is involved and engaged with business management, the green innovation and the internal entrepreneurship is made easier.

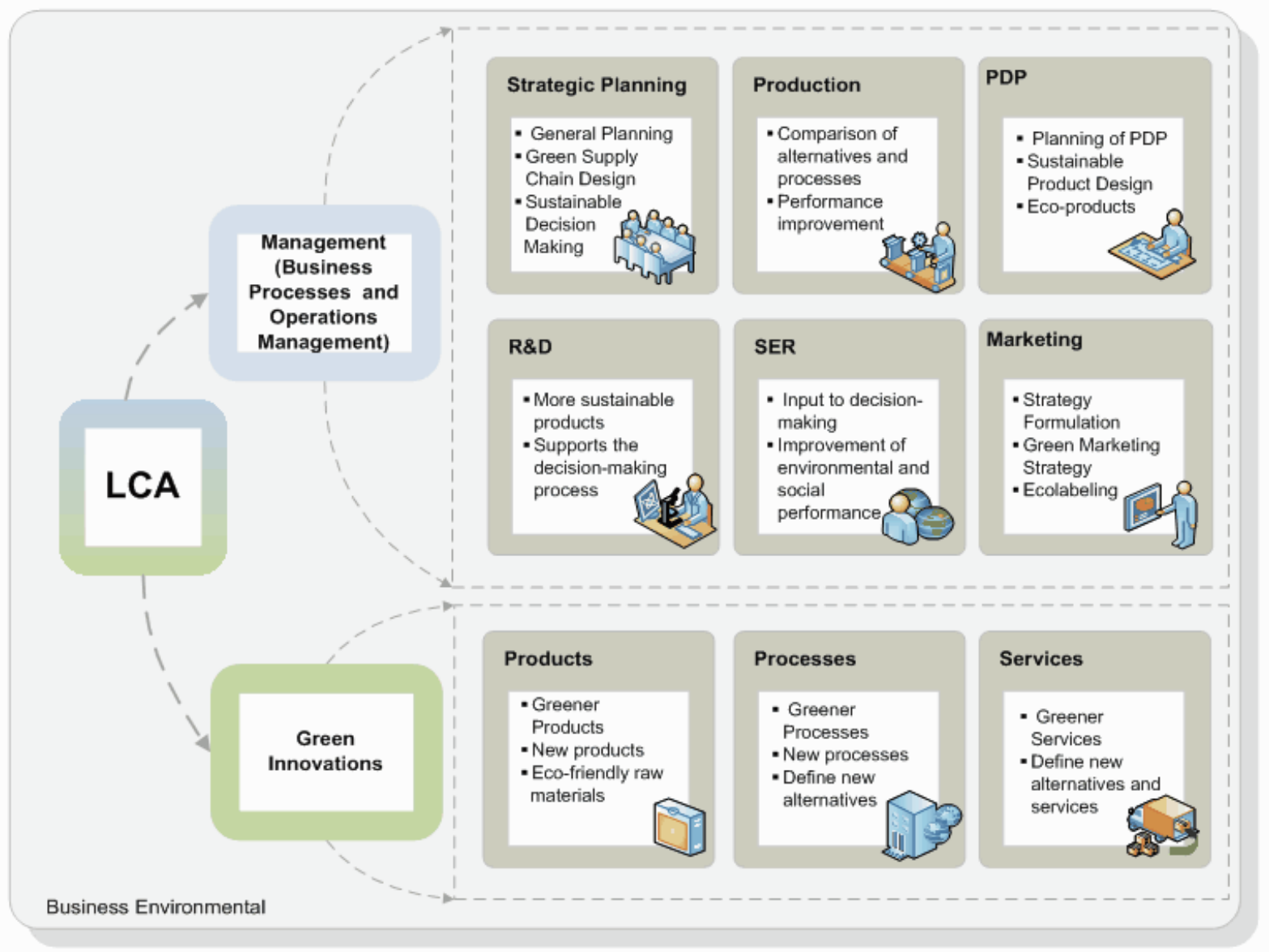

Figure 2. LCA benefits and applications in environmental business

ISSN: 07I 8-2724. (http://www.jotmi.org)

Journal of Technology Management \& Innovation (C) Universidad Alberto Hurtado, Facultad de Economía y Negocios. 


\section{LCA and Management}

(Bussiness Processes and Operations Management)

Life cycle thinking is a business management approach that can be used to guarantee a more sustainable management of the value chain. It can be used to direct, organize, analyze and manage information related to the product. It also can provide continuous improvement activities throughout the life cycle (UNEP/SETAC, 2009).

Company's leaders use the life cycle management to make more sustainable value chains and are applying it to create value. 3M, Eskom and Veolia Environnement, use the life cycle management to increase efficiency through the reduction of energy, reducing the use of materials and water.Veolia Environnement uses life cycle management to support the fundamental choices in technology. Eskom uses life cycle management to support important investment decisions. Alcan Packaging uses life cycle management for product development and for competitive advantage (UNEP/SETAC, 2009). For all these factors, the LCA can contribute to decisionmaking in various aspects as seen previously in Figure 2:

\section{Strategic Planning}

LCA can be used to assist in the general planning of the organization and motivate internal entrepreneurship. In Alcan, LCA is used for a variety of applications to company entrepreneurship. These include the strategic planning, marketing, products and Alcan benchmarking against competitors, as well as applications for improving environmental performance (Rebitzer and Buxmann, 2005).

LCA can also be used for the design of the supply chain. Newe et al. (2010) incorporates indicators of LCA in development of green supply chain projects (green supply chain design) and operation. Environmental impact indicators are incorporated into a dynamic model of the supply chain, along with profit and customer satisfaction. The sustainability of the project and various operational decisions can be evaluated comprehensively.

\section{Production}

In relation to the production process, LCA can be used to compare a new process with a process standard, aimed at getting the same final product, identifying improvements that can be applied in a more efficient way (Rebitzer and Buxmann, 2005).

Rebitzer and Buxmann (2005) use LCA to analyze a standard process in comparison with a new process. They were considered beyond the criteria of the technical feasibility, costs, quality aspects, and criteria related to environmental aspects. The results obtained could be used for implementation of new internal improvements.

Gebreslassie et al. (2010) incorporated LCA in project development and optimization of processes to establish a link between the environmental, operations and economic impacts of the process. Löfgren, Tillman and Rinde (20II) developed a method based on LCA to support improvement projects in a factory. This model allows evaluating the environmental performance of a production system that helps managers to identify potential areas of improvement.

\section{Product Development Process (PDP)}

Innovation and new product strategies are generally associated with an entrepreneurial approach to competitive advantage (Dess, Lumpkin and, Mcgee, 1999). In this context, LCA can be used to support decision making in product development projects, assisting in development planning and implementation of the projects.

According to Thabrew (2009) the concept of life cycle is a way to understand and visualize a broader range of upstream and downstream consequences of decisions in development planning and implementation.Vinodh and Rathod (2010) use LCA project design to integrate environmental requirements in all stages of product development, in addition to the traditional requirements of cost/profit.

Yang and Chen (20I2) use LCA for the eco-product design, evaluating innovative ideas to design environmentally friendly products. The evaluation of the new design is performed to verify if it is more efficient then what is currently available. This is done while it is still in the concept design stage.

\section{Research and Development (R\&D)}

LCA can assist in the research and development process (R\&D) for obtaining more sustainable products. The highquality environmental information is created by LCA to support the decision making in R\&D. Manda, Blok and Patel (20I2) have used LCA in the R\&D process of printing paper with reduced environmental impacts. LCA assists in the choice of several types of pulp and coatings for choosing a new product configuration and the associated processes, evaluating its performance from an environmental point of view.

\section{Social and Environmental Responsibility (SER)}

The growing concerns around the use of natural resources bring the challenge of incorporating in the innovation process the factors related to the environmental and social responsibility (Caetano, Araújo ande Amaral, 20I2). 
LCA provides a basis for the evaluation of potential improvements in the environmental and social performance of a product system (Pieragostini, 20I2). It can be used in this context as an input to decision-making regarding the choice of waste management systems, or strategic decisions concerning the priority of the use of resources. LCA is able to provide a general overview of the different environmental aspects of waste management strategies This tool makes it possible to compare the human health and environmental impacts of these options (Cherubini, Bargigli and, Ulgiati, 2009).

Wang, Templer, and Murphy (20I2) use LCA for comparison of three scenarios for waste management of papers (bioethanol production, recycling and incineration with energy recovery). It was possible to verify that the environmental profiles of each system vary significantly. This variation affects the results of the comparisons made between the scenarios. LCA enable them to choose the option that has the least impact on the environment and to human health.

\section{Marketing}

LCA can be used for the definition of marketing strategies of the organization, disseminating the advantages related to the products compared to other existing products.

According to the UNEP/SETAC (2009) LCA can assist in decision-making related to marketing, for example, for the implementation of an eco-labeling project (Eco labeling), or the environmental statement of the product. This emphasizes that LCA allows you to develop a "green" marketing strategy based on the product recycling possibilities.

With all that has been displayed, it can be perceived that LCA allows to identify opportunities to improve the environmental performance of products in various points in its life cycle (UNEP/SETAC, 2009). Thus, it becomes evident the importance of LCA as a tool for management. In this sense, its application can contribute significantly to the creation of green innovations within organizations.

\section{LCA and Green Innovations}

Innovation is seen as a strategic issue in the business world. Effective, sustained innovation remains one of the great challenges facing organization (Crane and, Meyer, 20II).

The entrepreneurship and innovation are a key point for the success of companies in an environment of intense technological development, creativity and, at the same time, concerns about greener products, processes and services. The insertion of environmental concerns into innovation process is an important step (Carvalho ande Barbieri, 20I2). In this sense, LCA can provide basic technological changes for the creation of green innovations.

The green innovation presents itself as a dynamic capacity of collective activity through which the organization creates and modifies its operating routines in search of greater effectiveness in relation to environmental impacts (Yam et al., 2004).

It is generally perceived that green innovations help firms to become more entrepreneurial, enhance environmental performance, minimize waste and achieve cost savings, and consequently promote efficiency and synergy among business partners and their lead corporations (Lin and, Ho, 2008).

The green factors, including innovations, may influence on international business activities and competitiveness of companies. Greener performance is a factor that may be used in order to develop competitiveness, but it must be analyzed within the perspective of value for the customers (Moen and Jørgensen, 2010). In addition to the above discussions, the use of LCA can promote green innovations in products, processes and services of a company (Figure 2) (Tseng et al., 2009).

\section{Products innovation}

The prospect of LCA identifies and quantifies environmental impacts in order to analyze and list what phases of the product life cycle has more considerable environmental impact (Cambria and Pierangeli, 20I2). This is one of the primary purposes of LCA: the identification of so-called "hot-spots". This term is commonly used in LCA studies to identify activities during the life cycle of the product that has significant contribution to the total potential impact associated with the product (Jefferies et al., 20I2). In this sense, the identification of hot-spots can direct actions and investments for the production of greener and news products.

Different LCA studies reveal green innovation actions from the application of LCA.The study of Madival et al. (2009) assesses three types of polymeric packaging in relation to the impacts generated in the production, use and disposal. With the evaluation, it was identified and selected a packaging with lesser environmental impact throughout its life cycle.

Tharumarajah and Koltun (2007) describe an application of LCA in order to evaluate the environmental impact of a new product.A new magnesium engine block was compared with a cast-iron block. The study showed that the use of the new product offers environmental advantages.

Russet et al. (20II) presented another application of LCA for the selection of an eco-friendly raw material. There was 
an environmental impact assessment for wooden briquettes of charcoal made from eucalyptus wood, making it possible to analyze the green innovation in different raw materials.

The application of LCA in products allows decision makers and policy makers to evaluate plausible alternatives for green innovation in products, processes and services.

\section{Processes innovation}

Results of LCA generate information that supports implementations of improvements and green innovations in different processes (Yan, Humphreys and Holden, 20I I; Pilgrim et al., 2006).

In this sense, LCA studies report green innovations related to processes. Pilgrim et al. (2006) used LCA to compare the environmental impact between a process of drying sewage waste and an innovative thermal drying process. The study supports that the new process is greener (greener process). In another study (Benetto, Becker and Welfring, 2009) it was compared the environmental performance of a wood drying process in the production of wood-based panels. The study supports that the new proposed process is innovative in the sector and presents fewer environmental impacts.

Rodríguez et al. (20I I) presents two case studies using LCA. In the first one, they compared car fuel alternatives and, in the second, were evaluated the generation of electrical energy from bio waste. When defining new alternatives in processes it is important to find out how environmentally friendly and sustainable these alternatives are and which of them will ensure a major improvement and provide innovations in environmental issues.

In addition to enabling green innovations in products and processes, LCA can be a viable alternative to map the impacts arising from the services of a company.

\section{Service innovations}

Find greener services, define new alternatives for services and work with new services from smaller environmental impacts are among the green innovations that can be achieved through the application of LCA.

A model based on the principles of LCA for the impact evaluation is presented by $\mathrm{Li}$, Zhu and Zhang (2010) the model is intended to serve as a support tool to identify the main environmental impact factors in building and optimizing the planning of buildings. In general, the results allow you to select greener services for a sustainable building.
Abdallah et al. (20/2) applies LCA to propose a green innovation in the supply chain of a company. The sample case study is presented with a life cycle assessment of three scenarios of supply chain based on different carbon emissions costs.

In this context, another study (Brave et al., 20II) also used LCA to evaluate the impacts of a supply chain. Alternatives were analyzed for the reduction of environmental impacts and suggestions for innovations in logistic services of wood biomass. In general, the results of LCA show its importance in the creation of green innovation, the decision-making process and the management of an organization.

\section{Conclusions}

One of the greatest challenges that will rule this decade must surely be the organizations become more entrepreneurial and at the same time maintaining more sustainable and innovative results.

Companies resort to new tools of management to become more entrepreneurial, ensure competitiveness and achieve greener and innovative results. In this aspect, LCA is a crucial tool for companies wishing to reach results of excellence and to facilitate green innovations.

Thus, the use of LCA can be a new way to promote the internal corporate entrepreneurship as a competitive differentiator.The tool makes possible the identification of points of improvement and innovations in products, processes and services. In business management, different organizational sectors can be supported, and can be a part of the decisionmaking process towards issues such sustainability, green building, green purchasing, carbon storage, climate change, eco-innovation, green economy, value create, and many others.

\section{Acknowledgements}

The authors would like to thank the financial support under CAPES and CNPq.

\section{References}

ABDALLAH, T., Farhat, A., Diabat, A., Kenned, S. (20/2). Green supply chains with carbon trading and environmental sourcing: Formulation and life cycle assessment. Applied Mathematical Modelling, 36(, 9), 427I-4285.

BAS, T. G., Amoros, E., Kunc, M. (2008). Innovation, Entrepreneurship and Clusters in Latin America Natural Resource - Implication and Future Challenges. Journal of Technology Management and Innovation, 3(4), 52-65. 
BENEDETTO, L. D., Klemes, J. (2009). The Environmental Performance Strategy Map: an integrated LCA approach to support the strategic decision-making process. Journal of Cleaner Production, 17(10), 900-906.

BENETTO, E., Becker, M., Welfring, J. (2009). Life Cycle Assessment of Oriented Strand Boards (OSB): from Process Innovation to Ecodesign. Environmental Science \& Technology, 43, (I5), 6003-6009.

BOCKEN, N. M. P, Allwood, J. M., Willey, A. R., King, J. M. H. (20I2) Development of a tool for rapidly assessing the implementation difficulty and emissions benefits of innovations. Technovation, 32 (I), |9-3I.

BORGHI, A. D., Binaghi, L., Borghi, M. D., Gallo, M. (2007). The application of the environmental product declaration to waste disposal in a sanitary landfill. The International Journal of Life Cycle Assessment, 12, (I), 40-49.

CAETANO, M., Araújo, J. B., Amaral, D. C. (2012). A Framework for the Application of Eco-efficiency to the Technology Development Process. Journal of Technology Management \& Innovation, 7, (2), 28- 38.

CAMBRIA, D., Pierangeli, D. (20I2). Application of a life cycle assessment to walnut tree high quality wood production: a case study in southern Italy. Journal of Cleaner Production, 23(I), 37-46.

CARVALHO, A. P., Barbieri, J. C. (20I2). Innovation and Sustainability in the Supply Chain of a Cosmetics Company: a Case Study.Journal of Technology Management \& Innovation, 7, (2), I44-I56.

CHERUBINI, F., Bargigli, S., Ulgiati, S. (2009). Life cycle assessment (LCA) of waste management strategies: Landfilling, sorting plant and incineration. Energy, 34, (I2), 2II6-2I 23.

CRANE, F. G., Meyer, M. H. (20I I). The Challenges of Innovation in American Companies:An Executive Ethnographic . Journal of Technology Management \& Innovation, 6, (4), 193204.

DE BENEDETTO, L., Klemeš, J. (2009). O Mapa Estratégico de Desempenho Ambiental: um sistema integrado LCA abordagem para apoiar a estratégica decisão - tomada processo. Journal of Cleaner Production, 17, (10), 900-906.

DESS, G. G., Lumpkin, G. T., Mcgee, J. E. (1999). Linking Corporate Entrepreneurship to Strategy, Structure and Process: Suggested Research Directions. Entrepreneurship Theory and Practice, 23, (3), 85-87.
FINNVEDEN, G., Hauschild, M. Z., Ekvall, T., Guineé, J., Heijungs, R., Hellweg, S., Koehler,A., Pennington, D., Suh, S. (2009). Recent developments in Life Cycle Assessment. Journal of Environmental Management, 9I(I), I-2I.

GARRIGUES, E., Corson, M. S., Angers, D. A., Werf, H. M. G. V. D.,Walter, C. (20I2). Soil quality in Life Cycle Assessment: Towards development of an indicator. Ecological Indicators, 18(7), 434-442.

GAUDREAULT, C., Samson, R., Stuart, P. R. (2010). Energy decision making in a pulp and paper mill: Selection of LCA system boundary. The International Journal of Life Cycle Assessment, I5, (2), I98-2II.

GEBRESLASSIE, B. H., Guillén-Gosálbez, G., Jiménez, L., Boera, D. (20I0). A systematic tool for the minimization of the life cycle impact of solar assisted absorption cooling systems. Energy, 35, (9), 3849-3862.

GOMES, C. M., Kruglianskas, I., Scherer, F. L. (20I I). Innovation Management for Sustainable Development Practices in the Internalization Context. Journal of Technology Management \& Innovation, 6, (2), I I0-I 27.

GUINÉE, J. B., Gorée, M., Heijungs, R., Huppes, G., Kleijn, R., Koning, A. de., Oers, L. V., Wegener, S. A., Suh, S., Udo, H. H. A., Bruijn, H., Duin, R. V., Huijbregts, M. A. J. et al. (200I). Handbook on Life Cycle Assessment Operational Guide to the ISO Standards. Publisher: Kluwer Academic Publishers, Dordrecht.

GUINÉE, J. B., Reinout, H., Gjalt, H., Zamagni, A., Masoni, P., Buonamici, R., Ekvall, T., Rydberg, T. et al. (20II). Life Cycle Assessment: Past, Present, and Future. Environmental Science \& Technology, 45, (I), 90-96.

HALL,J. K., Daneke, G.A., Lenox, M.J. (20I0). Sustainable development and entrepreneurship: Past contributions and future directions. Journal of Business Venturing, 25(5), 439-448.

ISO Norm 14040:2006, Life cycle assessment: Principles and framework. Environmental management (ISO) 2006a.

ISO Norm I 4044:2006, Life cycle assessment: Requirement and guidelines. Environmental management (ISO) 2006b.

JEFFERIES, D., Muñoz, I., Hodges, J., King, V. J., Aldaya, M., Ercin, A. E., Canals, L. M., Hoekstra, A. Y. et al. (20I2). Water Footprint and Life Cycle Assessment as approaches to assess potential impacts of products on water consumption: Key learning points from pilot studies on tea and margarine. Journal of Cleaner Production, 33(9), I55- 166. 
KLÖPFFER,W. (20I2). The critical review of life cycle assessment studies according to ISO 14040 and 14044: rigin, purpose and practical performance. The International Journal of Life Cycle Assessment, 17(9), I-7.

KOFFLER, C., Schebek, L., Krinke, S. (2008). Applying voting rules to panel-based decision making in LCA. The International Journal of Life Cycle Assessment, 13, (6), 456-467.

KUCKERTZ,A.,Wagner, M. (20I0). The influence of sustainability orientation on entrepreneurial intentions - Investigating the role of business experience. Journal of Business Venturing, 25(5), 524-539.

LI, X., Zhu,Y., Zhang, Z. (20I0).An LCA-based environmental impact assessment model for construction processes. Building and Environment, 45, (3), 766-775.

LIAMSANGUAN, C., Gheewala, S. H. (2008). LCA: A decision support tool for environmental assessment of MSW management systems. Journal of Environmental Management, 87(I), 132-138.

LÖFGREN, B.,Tillman, A., Rinde, B. (20II). Manufacturing actor's LCA. Journal of Cleaner Production, 19(17-18), 20252033.

MADIVAL, S.,Auras, R., Singh, S. P., Narayan, R. (2009).Assessment of the environmental profile of PLA, PET and PS clamshell containers using LCA methodology. Journal of Cleaner Production, I7(I3), I I83-I I94.

MANDA, B. M. K., Blok, K., Patel, M. K. (20I2). Innovations in papermaking: An LCA of printing and writing paper from conventional and high yield pulp. Science of the Total Environment, 439(22), 307-320.

MENESES, M., Pasqualino, J., Castells, F. (2012). Environmental assessment of the milk life cycle:The effect of packaging selection and the variability of milk production data. Journal of Environmental Management, 107(18), 76-83.

MOEN, Ø., JØrgensen, R. B. (2010). The New Managerial Challenge:Transforming Environmental and Health Issues to Competitive Advantages. Journal of Technology Management \& Innovation, 5(2), 24-36.

MORRIS, M. H., Vuuren, J. V., Cornwall, J. R., Scheepers, R. 2009. Properties of balance:A pendulum effect in corporate entrepreneurship. Business Horizons, 52(5), 429-440.

NEWE, E. S.,Adhitya,A., Halim, I., Srinivasan, R. (2010). Green Supply Chain Design and Operation by Integrating LCA and Dynamic Simulation. Computer Aided Chemical Engineering, 28(1), 109-1 I4.
ÖZDEMIRCI, A. (20II). Corporate Entrepreneurship and Strategy Process: A Performance Based Research on Istanbul Market. Procedia Social and Behavioral Sciences, 24(I5), 6II-626.

PACHECO, D. F., Dean, T. J., Payne, D. S. (20I0). Escaping the green prison: Entrepreneurship and the creation of opportunities for sustainable development. Journal of Business Venturing, 25(5), 464-480.

PARRISH, B. D. (20I0). Sustainability-driven entrepreneurship: Principles of organization design. Journal of Business Venturing, 25(5), 5I 0-523.

PASQUALINO, J., Meneses, M., Castells, F. (20II). The carbon footprint and energy consumption of beverage packaging selection and disposal. Journal of Food Engineering, I03(4), 357-365.

PEREGRINA, C. A., Lecomte, D., Arlabosse, P., Rudolph, V. (2006). Life cycle assessment (LCA) applied to the design of an innovative drying process for sewage sludge. Process Safety and Environmental Protection, 84, (4), 270-279.

PIERAGOSTINI, C., Mussati, M. C., Aguirre, P. (2012). On process optimization considering LCA methodology. Journal of Environmental Management, 96(I), 43-54.

POESCHL, M., Ward, S., Owende, P. (20I2). Environmental impacts of biogas deployment e Part II: life cycle assessment of multiple production and utilization pathways. Journal of Cleaner Production, 24(5), 184-20I.

REBITZER, G., Buxmann, K. (2005). The role and implementation of LCA within life cycle management at Alcan. Journal of Cleaner Production, 23, (13), 1327-1335.

RODRÍGUEZ, R. M. A., Ruyck, J., Díaz, R. P., Verma, C. K., Bram, S. (20II). An LCA based indicator for evaluation of alternative energy routes. Applied Energy, 88, (3), 630-635.

ROUSSET, P., Pires, A. C., Sablowski, C., Rodrigues, T. (20I I). LCA of eucalyptus wood charcoal briquettes. Journal of Cleaner Production, 19, (14), 1647-1653.

ROY, P., Nei, D., Orikasa,T., Xu, Q., Okadome, H., Nakamura, N., Shiina, T. 2009. A review of life cycle assessment (LCA) on some food products. Journal of Food Engineering, 90(I), I-I0.

SÁNCHES, A., Lago, A. Xavier, F., Ribera, J. (20I I). Innovation Management Practices, Strategic Adaptation, and Business Results: Evidence from the Electronics Industry. Journal of Technology Management and Innovation, 6(2), 14-39.

ISSN: 07 I8-2724. (http://www.jotmi.org) 
SHAFIE, S. M., Mahlia, T. M. I., Masjuki, H. H., Rismanchi, B. (2012). Life cycle assessment (LCA) of electricity generation from rice husk in Malaysia. Energy Procedia, I4(I), 499-504.

THABREW, L.,Wiek,A., Ries, R. (2009). Environmental decision making in multi-stakeholder contexts: applicability of life cycle thinking in development planning and implementation. Journal of Cleaner Production, 17(1), 67-76.

THARUMARAJAH, A., Koltun, P. (2007). Is there an environmental advantage of using magnesium components for lightweighting cars?. Journal of Cleaner Production, I5(II-I2), 1007-1013.

TSENG, M. L. (2010). Using linguistic preferences and grey relational analysis to evaluate the environmental knowledge management capacities. Expert Systems with Applications, $37,(1), 70-81$.

TSENG, M. L., Divinagracia, R., Divinagracia, L. (2009). Evaluating firm's sustainable production indicators in uncertainty. Computers \& Industrial Engineering, 57, (4), I393- 1403.

UNEP/SETAC. (2009). Life Cycle Management: How business uses it to decrease footprint, create opportunities and make value chains more sustainable. UNEP/SETAC, 2009.

VALENTE, C., Spinelli, R., Hillring, B. G. (20I I). LCA of environmental and socio-economic impacts related to wood energy production in alpine conditions:Valle di Fiemme (Italy). Journal of Cleaner Production, 19, (17), 1931-1938.

VARŽINSKAS,V., Staniškis, J. K., Knašyte, M. (20I2). Decisionmaking support system based on LCA for aseptic packaging recycling. Waste Management and Research, 30, (9), 93I-939.

VINODH, S., Rathod, G. (2010). Integration of ECQFD and LCA for sustainable product design. Journal of Cleaner Production, I8(8), 833-842.

WANG, L., Templer, R., Murphy, R. J. (2012). A Life Cycle Assessment (LCA) comparison of three management options for waste papers: Bioethanol production, recycling and incineration with energy recovery. Bioresource Technology, I20(18), 89-98.

WELZ, T., Hischier, R., Hilty, L. M. (20I I). Environmental impacts of lighting technologies: Life cycle assessment and sensitivity analysis. Environmental Impact Assessment Review, 3I(3), 334-343.

YAM, R. C. M., Guan, J. C., Pun, K. F., Tang, E. P.Y. (2004).An audit of technological innovation capabilities in chinese firms: some empirical findings in Beijing, China. Research Policy, 33, (8), I I 23- I I 40.

ISSN: 07/8-2724. (http://www.jotmi.org)

Journal of Technology Management \& Innovation (c) Universidad Alberto Hurtado, Facultad de Economía y Negocios.
YAN, M.J., Humphreys, J., Holden, N. M. (20I I).An evaluation of life cycle assessment of European milk production. Journal of Environmental Management, 92, (3), 372-379.

YANG, C. J., Chen, J. L. (20I2). Forecasting the design of ecoproducts by integrating TRIZ evolution patterns with CBR and Simple LCA methods. Expert Systems with Applications, 39, (3), 2884-2892. 